\title{
THE EFFECT OF MAMMALIAN LACTOGENIC HORMONE ON LOWER CHORDATES
}

\author{
By D. B. Carlisle \\ The Plymouth Laboratory
}

If a male dogfish is held in the hand and its belly stroked firmly backwards with the ball of the thumb a fluid can be expressed from the cloaca. In my experience this fluid in a fresh animal invariably contains sperm, whatever the season of the year. After a period of inanition, however, sperm eventually disappears from the cloacal fluid. Such an animal is a convenient test object for gonadotropic activity by a method which closely parallels the toadpregnancy test of Galli Mainini (1947).

In a former paper I have shown that ascidians respond to an injection of chorionic gonadotropin by ovulation and release of sperm into the water (Carlisle, I95I). Anterior lobe pituitary gonadotropic extract (Praephyson) has the same effect in equivalent doses, when tested on Ciona intestinalis.

\section{Materials used}

The anterior lobe gonadotropic hormone used was the German Praephyson (Chemische Fabrik Promonta, Hamburg), stated to be assayed at I5 m.u. luteinizing hormone per ml. Reassayed by me on mice by the AscheimZondek test it titred $70 \mathrm{i.u} . / \mathrm{ml}$.

Chorionic gonadotropin was extracted from human pregnancy urine by Dr W. M. S. Russell and myself, and assayed by the Ascheim-Zondek test and by the Xenopus ovulation test at I Io i.u./mg. This material was dissolved immediately before use at the rate of I $\mathrm{mg}$. $/ \mathrm{ml}$. of distilled water, yielding a solution containing I Io i.u. $/ \mathrm{ml}$.

The lactogenic hormone was extracted from human post-partum urine. Urine was taken $\mathrm{I}-7$ days post partum, at which time there is the highest content of lactogenic hormone. After adjusting the $\mathrm{pH}$ to approximately the isoelectric point of the hormone $(\mathrm{pH} c .5 \cdot 6) 5 \%$ by volume of a saturated solution of benzoic acid in acetone was added slowly with stirring. Microcrystals of benzoic acid are thus formed which supply a large surface for the adsorption of the hormone and other proteins. The mixture was left in a refrigerator overnight. The benzoic acid with its adsorbed proteins was then filtered off. The filtrate was then re-extracted in the same way. The combined fractions of benzoic acid were washed with distilled water and then the benzoic acid washed out with several changes of absolute acetone, in which the proteins are insoluble. The proteins are thus left behind as a precipitate, 
free of benzoic acid. The precipitate is dissolved in 50\% acetone, and any remaining insoluble material discarded. The dissolved material was precipitated by raising the acetone concentration above $92 \%$ and filtered off.

This precipitate was then purified and crystallized by the dilute acetone method of White, Bonsnes \& Long (I942).

This method of crystallization has apparently failed in the hands of a number of workers. The method depends, in the last analysis, on the isoelectric precipitation of the hormone, with the precipitation delayed by the addition of acetone to give time for crystals to form, instead of a fast amorphous precipitation. Obviously, then, the final solution must be at the isoelectric point of the hormone at the time of precipitation. In the outline of the method given by White $e t$ al. the adjustment of the solution to the isoelectric point before the addition of acetone is prescribed, but no mention is made of the necessity of readjusting the $\mathrm{pH}$ after the addition of acetone. Acetone, even of Analar grade, frequently departs quite widely from the desired $\mathrm{pH}$, and correspondingly the solution to which this acetone is added is altered in $\mathrm{pH}$ away from the isoelectric point. Under these conditions crystallization, or indeed precipitation, is unlikely to occur. It is thus essential to readjust the $\mathrm{pH}$ of the mother liquor to the isoelectric point of the hormone after the addition of acetone.

The yield of crystalline lactogenic hormone by this method is approximately $20 \mathrm{mg} / 1$. of urine. It assays at about $25 \mathrm{i}$.u. $/ \mathrm{mg}$. as tested by the pigeon-crop method. When tested by the Ascheim-Zondek test for gonadotropic content, Io mg. administered to each of five mice gave no response. Ten i.u. of chorionic gonadotropin ( $0.09 \mathrm{mg}$.) produced a positive response in a parallel test.

\section{Experimental data}

An injection of I or $2 \mathrm{mg}$. of chorionic gonadotropin dissolved in distilled water into starved male dogfish-four tests at each level of dosage-stimulated a reappearance of sperm in the cloacal fluid. An injection of $0.5 \mathrm{mg}$. had no such effect on six animals. Presumably this was below the threshold of activity.

An injection of $2 \mathrm{mg}$. of lactogenic hormone dissolved in distilled water into each of seven animals stimulated the reappearance of sperm in the cloacal fluid.

An injection of I ml. distilled water into each of seven animals had no effect.

An injection of $\mathrm{I} \cdot 5 \mathrm{ml}$. praephyson into each of six animals stimulated the reappearance of sperm in the cloacal fluid.

An injection of $0.5 \mathrm{ml}$. praephyson into each of six animals had no effect.

An injection of I mg. of chorionic gonadotropin into each of ten Ciona provoked ovulation and sperm discharge. An injection of $\mathrm{I} \mathrm{ml}$. praephyson into each of five Ciona provoked ovulation and sperm discharge.

An injection of I mg. lactogenic hormone into each of ten Ciona provoked ovulation and sperm discharge. 
An injection of $0.1 \mathrm{mg}$. chorionic gonadotropin into each of ten Ciona had no effect.

An injection of I ml. distilled water into each of ten Ciona had no effect.

The results of these tests are listed in Table I. The positive effect in dogfish was as already stated, that in Ciona was ovulation and sperm discharge.

\section{TABLE I}

(c.G. = chorionic gonadotropin, L.T.H. = lactogenic hormone, each dissolved in distilled water.)

\begin{tabular}{ll}
\multicolumn{2}{c}{ Injection } \\
$\begin{array}{ll}\text { Dose } \\
\text { C.G. }-2 \mathrm{mg} .\end{array}$ \\
C.G. & $0.5 \mathrm{mg}$. \\
L.T.H. & $2 \mathrm{mg}$. \\
Distilled water & I $\mathrm{ml}$. \\
Praephyson & $\mathrm{I} .5 \mathrm{ml}$. \\
Praephyson & $0.5 \mathrm{ml}$. \\
C.G. & I mg. \\
Praephyson & I ml. \\
L.T.H. & I $\mathrm{mg}$. \\
C.G. & O. I mg. \\
Distilled water & I ml.
\end{tabular}

\begin{tabular}{|c|c|c|}
\hline Subject & $\begin{array}{c}\text { No. of } \\
\text { individuals }\end{array}$ & Effect \\
\hline Dogfish, ô & 7 & + \\
\hline Dogfish, ô & 6 & 0 \\
\hline Dogfish, ô & 7 & + \\
\hline Dogfish, $\widehat{0}$ & 7 & 0 \\
\hline Dogfish, $\hat{0}$ & 6 & + \\
\hline Dogfish, $\widehat{\sigma}$ & 6 & o \\
\hline Ciona & IO & + \\
\hline Ciona & 5 & + \\
\hline Ciona & Io & + \\
\hline Ciona & IO & 0 \\
\hline Ciona & IO & 0 \\
\hline
\end{tabular}

\section{Comment}

Since ro mg. lactogenic hormone had less gonadotropic effect on mammals than $0.09 \mathrm{mg}$. chorionic gonadotropin, and since $0.5 \mathrm{mg}$. chorionic gonadotropin was below the threshold dosage for the dogfish, then the spermatic activity of the lactogenic hormone on the dogfish could not be due to an impurity of gonadotropin contained in the lactogenic hormone, for the assay on mice indicated that I mg. of lactogenic hormone must contain less than $0.009 \mathrm{mg}$. (I i.u.) of gonadotropic hormone. A similar argument applies to the comparative dosages on Ciona. Evidently, then, it must be the lactogenic hormone itself which has had the gonadotropic effect on these two animals. Physiologically speaking, they seem unable to distinguish between the two hormones and respond, apparently, to both of them in the same way. Are we here perhaps at an evolutionary level before the differentiation of a primitive sexual hormone of the pituitary into several different hormones with different functions?

This work was performed in the laboratories of the Department of Comparative Anatomy and Zoology, Oxford, and of the Zoological Station at Naples, while holding a Beit Memorial Fellowship for Medical Research, the Oxford Naples Scholarship, a Senior Demyship of Magdalen College, Oxford, and grants from the Browne Fund of the Royal Society, at various times. I wish to thank Prof. A. C. Hardy, F.R.S., Prof. R. Dohrn, Dr A. E. Needham and Dr W. M. S. Russell. 


\section{SUMMARY}

Lactogenic hormone of mammals has a gonadotropic effect on dogfish and on Ciona, an ascidian. This activity resides in the hormone itself and not in any impurity.

\section{REFERENCES}

CARLISLE, D. B., I95I. On the hormonal and neural control of the release of gametes in ascidians. F. exp. Biol., Vol. 28, pp. 463-72.

Galli Mainini, C., I947. Pregnancy test using the male toad. F. clin. Endocrinol., Vol. 7, pp. 635-8.

White, A., Bonsnes, R. W. \& Long, C. H. N., I942. Prolactin. F. biol. Chem., Vol. I43, pp. 447-64. 